\title{
A Conversation with Lynn Meskell
}

Lynn Meskell is PIK Professor of Anthropology in the School of Arts and Sciences, Professor in the Graduate Program in Historic Preservation, and curator in the Middle East and Asia sections at the Penn Museum. She is currently A.D. White Professor-at-Large at Cornell University (2019-2025). She holds Honorary Professorships at Oxford University and Liverpool University in the UK and the University of the Witwatersrand, South Africa. Over the past twenty years she has been awarded grants and fellowships including those from the Andrew W. Mellon Foundation, the National Science Foundation, the Australian Research Council, the American Academy in Rome, the School of American Research, Oxford University and Cambridge University. She is the founding editor of the Journal of Social Archaeology. Meskell has broad theoretical interests including socio-politics, archaeological ethics, global heritage, materiality, as well as feminist and postcolonial theory. Her earlier research examined natural and cultural heritage in South Africa, the archaeology of figurines and burial in Neolithic Turkey and daily life in New Kingdom Egypt.

Over the last decade, Meskell has conducted an institutional ethnography of UNESCO World Heritage, tracing the politics of governance and sovereignty and the subsequent implications for multilateral diplomacy, international conservation, and heritage rights. Employing archival and ethnographic analysis, her award-winning book. A Future in Ruins: UNESCO, World Heritage, and the Dream of Peace (2018, OUP New York), reveals UNESCO's early forays into a one-world archaeology and its later commitments to global heritage. Building on this research, she is currently examining the entwined histories of colonialism, internationalism, espionage and archaeology in the Middle East coupled with a new largescale survey project in Syria and Iraq to assess public opinion on heritage destruction and reconstruction. Other recent fieldwork explores monumental regimes of research and preservation around World Heritage sites in India and how diverse actors and agencies address the needs of living communities.

Martina Revello Lami: Thank you very much Lynn for joining us today! I'm particularly happy to have Professor Meskell here today because Lynn has been one of the sources of inspiration for our journal both as the editor of the Journal of Social Archaeology and more generally as a researcher committed to challenge common assumptions about the role of archaeology in the present. Thank you once again for accepting to answer our questions and without further ado let's jump right into it.

Heritage ethics and the politics of contemporary archaeology practice lie at the core of your research commitment. In your book Cosmopolitan Archaeologies, first published in 2009, you prompted archaeology scholars and practitioners to strike a fine balance between the ethical responsibilities we carry to the living communities with whom we work and the force of world conventions and international codes we are subjected to. More than a decade after, how far are we from reaching that balance?

Lynn Meskell: Thanks Martina and thank you for having me here and for organizing this meeting! Now, moving to your question, first of all I should probably say yes, the 2009 book is really about the sort of cosmopolitan responsibility, our responsibilities, as 
archaeologists in the rest of the world. But it actually goes back to my first book Archaeology Under Fire. I was still a student when I put that together and was already trying to get archaeologists to see their roles in what was happening in the Mediterranean, in the Middle East, and the Gulf: I was trying to see how we were also implicated in the struggles and conflicts of our time.

At that time some work on the relationship between nationalism and archaeology had been published already, yet I was trying to put the focus back on us: it was not simply a matter of looking at emblems that were used by nations, it was actually our fieldwork and ourselves as practitioners going out to other countries and carrying out our research while working with governments and being funded by other parties. Such interaction had an impact and I think that came out in the 1998 book very clearly. If then we move forward to Cosmopolitan Archaeologies, that book takes those ideas further and adds issues of ethics and responsibility to the picture. The book does not simply highlight that we are there, and we are doing something, it goes one step further to ask how our work as archaeologists fits into the struggles of ordinary people, who wins or loses, as I always say, in these kinds of equations.

I think such an awareness is becoming more mainstreamed if you just look at the number of articles and journals devoted to contemporary archaeology, public archaeology, heritage issues, community archaeology, however you want to frame it. It is a little like the trajectory with another topic I worked on, gender, which back in the 90 s used to be a sort of single issue or topic mainly addressed by women. Now gender archaeology has been incredibly incorporated and mainstreamed, it is taken for granted that issues of gender, class and race need to be considered in our narratives.

These were the issues we were trying to bring forward in the 90s and I think the same is true for the nexus between archaeology, heritage, and ethics. The way in which research and fieldwork reports are published and funded shows that there really is a sort of forward moving trajectory that is not just becoming a specialised take on thing at the end, but something that has to infuse all our work from the outset. It has been a slow and gradual move in archaeology, but it really ramped up and I think that the younger generation of archaeologists take that mission as a normal practice now. This of course does not mean that no more work is left to do, but we certainly are moving in the right direction.

Martina Revello Lami: It is comforting to hear that archaeologists and heritage professionals are moving in the right direction and I would add that your voice (among others) played a role in the path toward such awareness. And as you rightly mentioned, the way in which we now approach gender archaeology is a chief example on the progresses made in our discipline thus far.

Keeping in with the theme of archaeology and self-awareness, I would like to include in this conversation a specific attitude toward heritage that you framed as protectionism. In your works you often refer to the attempt to preserve certain valued sites for the global 
benefit of humanity as dangerously intertwined with Euro-American based development polities, neoliberalism instances and governmentality concerns at the expense of the immediate residents and stakeholders living in those sites. Archaeologists are the facilitators of such policies yet mostly excluded from drafting them. Awareness aside, what tools do we have to become more actively involved in decision-making processes?

Lynn Meskell: This is a good and complex question. First of all, I would start from the enormous amount of work archaeologists are doing abroad, outside their countries. One way to build a more involved, aware, and responsible professional profile as described in Cosmopolitan Archaeologies, is acknowledging that we must work more closely with local universities and research centres. In India, where I am currently conducting a research project, I have set up consortium in an attempt to become more involved with the practitioners across the country and strongly reject the colonial, extractive attitude of doing our fieldwork and then leaving. Having led several projects in Middle East, the Mediterranean, South Africa and India where I also set up exchange programs for students and researchers, I believe this is the way to go. And this is the way to work with governments as well: many of the people I have worked with on those exchanges ended up going into government and now we do have better linkages, which puts archaeology on a better platform in those countries. In India we are currently trying to start new degrees where a training in archaeology and heritage is provided to students who then will be most likely be working in the national archaeological survey. It was pivotal in this case to collaborate closely with the local authorities to have them part of the training as well.

In my opinion these are the type of actions that elevate archaeology and archaeologists to have some say or stake in the future of the sites as they affect local communities inevitably.

About the expression heritage protectionism, actually I do not recall having used that term, but it sounds very much like me. In fact, it can work on many levels. When you think of protectionism, it is about ring-fencing or securing certain sorts of expertise and countries and industries. We are as I said still quite colonial in our approach and that has not changed, certainly not in the regions where I have worked most. We do protect ourselves as experts and the UNESCO world does the same, so we may well say that this is a very Euro-American attitude that does not really value local expertise. Many of my students are working on the topic of authority, whether it is in India, the Gulf, or Eastern Europe. And as painful as it is, we must admit that we are still operating under the condition of being protected countries and protected professionals, which means getting all the authority and kudos without recognizing local expertise, which is not acceptable anymore.

The other side of protectionism is that it is always about the "stuff" and not the people. And as you know what governments do and also what World Heritage sanctions governments to do is to protect sites and places, not people. I have done some work that shows that once the World Heritage label is secured, it emboldens governments to be good heritage citizens, but not always to be very good to their own citizens. Being aware 
of the multi-layered nature of the World Heritage system entails to raise the intellectual state and the public profile of archaeologists.

At Penn I hold what is called the PIK Professorship which stands for "Penn Integrates Knowledge": in this capacity I spend my time collaborating with specialists based at the Design School, the Faculty of Medicine, the Wharton Business School and together we focus on corporate ethics applied to heritage systems and how to change those "protectionist" attitudes. It is a mix of being very interdisciplinary and getting archaeology on that stage that political science for instance has no problem with. Unlike historians and philosophers, archaeologists are always seen -as you said - as the person you might call if you come across "something old" on a construction site. We also need to have a stronger political, intellectual and cultural profile, which is something I am very keen to work towards.

Martina Revello Lami: The lack of a stronger political and cultural profile keeps being a major flaw in archaeology: we are so used to build fences around monuments to protect them from any danger that we end up doing the same to our discipline. Not making our data accessible equates building fences around our discoveries and in a way casts a shadow on our relationship with the public and their vague understanding of our role. Archaeologists are often perceived as in-between figures, something half-way an academic, an architect and a contractor. Expanding our networks and connecting our job more strongly with other disciplines and all parties involved in the protection and fruition of heritage is probably key here.

Lynn Meskell: I think one American archaeologist said a very long time that to be an archaeologist you must be a diplomat, a politician, a fundraiser and public speaker, as well as an excavator and everything else. And if you think about our jobs, particularly when we work abroad, we do have to deal with all these aspects as I have when I work with political scientists, economists, lawyers, international lawyers. To carry out our activities in those areas it is pivotal to be aware of all legal and ethical aspects, from indigenous rights to cultural property and land rights. On the other hand, there is also a need to reframe the current narrative about our work, which is still quite fetishized, I think. Archaeology is perceived as something very exotic and unless we break out of the pattern of being those people digging holes in the ground to find something that happened thousands of years ago rather than the present, then we are going to be stuck in that same unintellectual and irrelevant position, except if you are watching Discovery Channel.

Martina Revello Lami: True, we are still quite stuck in the Indiana Jones narrative! However, it is also difficult to grasp all legal and ethical issues while mastering different communication levels....

Lynn Meskell: Of course! I am not suggesting that archaeologists should take extra degrees in economics or law, I had students who have done that too and it is fantastic, however, we can certainly compensate our deficiencies by working in teams! Much of my current work has been carried out in partnership with people who are expert in their field 
and together we shape a different sort of project. I believe archaeologists are very used to a team ethos, unlike historians or philosophers. If anyone should embrace interdisciplinary collaboration, it should be us.

Martina Revello Lami: So far, we highlighted how political awareness, ethical responsibility and interdisciplinary collaboration are essential components to provide archaeologists with a stronger and more relevant profile. Now, moving to your more recent work "A Future in Ruins", I would like you to share with us your insider's view of the World Heritage program. In fact, while writing the book you have been granted access to UNESCO's World Heritage Committee meetings and events. As an official observer you witnessed the pressure exerted by powerful states, the extent of the lobbying and the dark side of heritage branding. With the largest number of sites on the World Heritage List, Italy definitely capitalised on the UNESCO brand, but not always implemented its expert recommendations. The money spent by Italian authorities is often put into hospitality industry rather than the maintenance of its monuments. National prestige and tourism revenues seem to have replaced the mandate of protecting heritage: do you think it is still possible to educate ourselves about the politics at work in cultural operations and reverse such trend?

Lynn Meskell: Another great and quite difficult question! Well, it is certainly easy to educate ourselves, that was the whole point of me writing that book in the first place: I wanted to educate myself and other archaeologists about the politics at work in such organizations. Actually, the project started in Oxford when Chris Gosden said to me "You know, it is fascinating that UNESCO is so internationally known and recognized and yet it does not seem to involve archaeologists at the level that you would imagine, and certainly that it once did. We do not know very much about the workings at UNESCO and yet we all work at UNESCO sites". I immediately replied that this would be a fantastic topic for a PhD dissertation, and I remember Chris saying, "Why don't you do it?". At that time, I was in Paris finishing my South Africa book and I happened to meet somebody who worked at UNESCO and it all just sort of went from there.

Chris's remark about what happened to archaeology at UNESCO sparked the idea of the book and when I got into the archives, I found out that archaeologists were instrumental at the setting up of the World Heritage Program and that all just dropped out over the years. I realised that we are not the major influential players when it comes to the Secretariat at the Paris headquarters or elsewhere. We are however present in the national delegations, perhaps less increasing as it goes on more politically, still archaeologists are involved in the process.

Coming back to your questions, we can educate ourselves, certainly by reading more about how the organization runs from people who have worked within it rather than simply read about it online. There has been a lot of speculation or what I call the industry of opinion, whereas one would google a site and do all their research online and eventually write a paper about UNESCO without knowing how it works pragmatically and who the decision makers are. 
Today all committee meetings are livestreamed and there are plenty of documents available showing how decisions are changed, manipulated and argued against, still supported no matter what. Like in any good research, you need to do the groundwork, and I spent eight years in the archives, meeting people working at UNESCO at the highest levels, national ambassadors, and then travelling across the organization's regional offices, be it in Thailand or Brazil, visiting sites accompanied by those who manage the UNESCO end of things. I had worked at World Heritage sites myself and as an archaeologist. I have seen those processes of inscription go through: the book is just the result of research. You do not have to be a mind-reader, I took my experience at UNESCO like any other archaeological project: gather your data, look at the textual and physical evidence and put them together. In a way I think today there is no excuse for archaeologists not knowing how UNESCO works. Perhaps ten or twenty years ago, not anymore. The whole process is far more public and accessible, thus educating ourselves is possible and that grants us with a greater say. We can certainly observe and better understand what does entail for a community having its own heritage nominated and then inscribed on the list. I witnessed what happens after the excitement about the process of inscriptions fades away: as soon as a site gets the UNESCO badge, nobody really cares when the community is pushed out and removed from any decision making and all the promises that the government have made them just evaporated.

We are quite self-absorbed when it comes to our projects and excavations, but we need the help of the community if we want to put in for grant or give a public lecture. Too often we do not care about the consequences and then we leave. We follow a project for one, ten, twenty summers, and then we leave. And we are back to the cosmopolitan issue about ongoing responsibility.

So, to answer your question, yes, we can absolutely know as much as we can now, and we can read first-hand information from people who have done the fieldwork and it is not just myself but many other colleagues who have done sustained, long-term work, season after season. In this sense, the key to educate ourselves is to become more ethically involved in the work we do. As I mentioned earlier, archaeologists are often called to do assess and evaluate a site within the UNESCO framework and it is their ethical responsibility to be aware about both the archaeological context and the administrative and legal terms of the process, instead of being caught up in consultancy culture and focusing only on the opportunity to add another (exotic) experience to their curriculum. Once again, we need to be responsible, do our homework instead of being seduced by the World Heritage brand itself.

Martina Revello Lami: So as archaeologists we do hold a privileged position that allows us to observe the World Heritage dynamic from within, and when building on solid groundwork we can probably be of some use at more levels, not only when heritage issues are at stake? 
Lynn Meskell: Yes, if you look at historians, anthropologists, philosophers, certainly political scientists, and economists, they have no qualms about standing up, speaking out, giving an opinion, talking to the press, while we haven't really as a discipline. We are much more reticent; we tend to retreat into our specialisms and overlook the conflicts and issues many communities are exposed to when a site becomes part of the World Heritage programme. As urban development unfolds, relocations and social violence frequently follow, and even though tangentially we are part of the process. In fact, another form of protectionism is the fear of not being granted with a permit to do research if we stand up to governments. Our level of self-interest is enormous because again, unlike historians, it is incumbent upon us to be in the field which forces us to strike a difficult balance between preserving our project and our team and being responsible citizens too. If you have to work under an oppressive regime or a predatory state, you will have to abandon that line of research eventually. And as someone who has changed research areas from Egypt to South Africa to Turkey to India, I can assure you that it is possible.

Martina Revello Lami: Be responsible, speak out, get more ethically involved, challenge oppressive regimes, well this sounds like a great manifesto for a more politically active and sustainable archaeology. Thank you very much Lynn for sharing your thoughts with us! 
252 LYNN MESKELL 